\title{
Index of Site Congestion for Effective Material Storage at Construction Site
}

\author{
Nurul Fathira Misron, Muhamad Azry Khoiry, Noraini Hamzah
}

\begin{abstract}
A project construction requires efficient management of materials storage. Systematic material storage ensures that the workflow of construction works is according to the schedule. Limited material storage will cause congestion at a construction site. The objective of this study is to generate a congestion index of construction for the material storage based on the congestion features and project site area. The survey questionnaire and site surveys methods were used in this study. The congestion index for the survey questionnaire was tested against 12 site congestion characteristics using Relative Important Index (RII). Site surveys have been carried out on 16 strata-type residential projects by identifying the total site area for calculation of congestion index using formula Non-Building Coverage Ratio (NBCR). The results showed that the congestion with the highest index of 0.8557 was a delay or change in the production schedule of the materials. The results of the site surveys have revealed that there are three sites with high levels of congestion with a range of less than 0.5. In conclusion, knowing the site congestion index can efficiently analyse site management strategies, including the management of material storage. Also, material management can create a more organised site schedule.

Keywords-Congestion Construction Site, Congestion Index,
\end{abstract} Material Storage, Material Management, Storage Strategy

\section{INTRODUCTION}

Congestion at a construction site can be a common occurance in every construction project. Congestion can happen when workspace allocated for construction material resource is limited or smaller than the required space (M. Kassem et al., 2015), (Rajiv Chavada et al., 2011), (R. D. Chavada et al., 2012) \& (N. R. Esfahan \& S. Razavi, 2015). The description is suppoted by Wu \& Chiu (2010), Low \& Chua (2017), Wang et al. (2018), Zhang et al. (2015) \& S.P. Dozzi et al. (1993), where space congestion is caused by inadequate site space and simultaneous activities can disturb the daily site operations (N. Pradhananga\& J. Teizer, 2014). Space is a resource that can create important issues during construction (Wu \& Chiu, 2010). Construction site space is a combination of energy source and components of building space, site arrangement space, operation space, equipment space and material storage space (Wu \& Chiu, 2010). In certain construction site with limited space, insufficient material storage to seggregate materials within its catogeries and it constantly changes with the current situations (Kaiman Li et al., 2019) \& (S.P. Dozzi et al., 1993).

\section{Revised Manuscript Received on 14 August, 2019.}

NurulFathiraMisron, Programme of Civil Engineering, Faculty of Engineering \& Built Environment, UniversitiKebangsaan Malaysia, Bangi, Malaysia

MuhamadAzryKhoiry, Programme of Civil Engineering\& Smart and Sustainable Township Research Centre (SUTRA), Faculty of Engineering \& Built Environment, UniversitiKebangsaan Malaysia, Bangi, Malaysia

NorainiHamzah, Programme of Civil Engineering\&Smart and Sustainable Township Research Centre (SUTRA), Faculty of Engineering \& Built Environment, UniversitiKebangsaan Malaysia, Bangi, Malaysia

Working site congestion will cause a distruption towards workflow and planned schedule which usually results in low productivity (R. Jongeling et al., 2008), (Zhang et al., 2015) \& (N. R. Esfahan \& S. Razavi, 2015). According to previous study (S.P. Dozzi et al., 1993), (Rajiv Chavada et al., 2011) \& (N. R. Esfahan \& S. Razavi, 2015), congestion can induce a dangerous practice and cause productivity lost within the whole product chain. The study by Vitaly Semenov et al. (2013) also stated that congestion in the operation site contributes to the lost of productivity between $10 \%$ to $40 \%$ and will increase when resource space is not planned efficiently causing a decrease in work efficiency up to $65 \%$ (congestion conflict). According to M. Kassem et al. (2015), the idea of reducing the size of workspace can cause higher congestion levels unless the amount of resource needed is reduced. Conflict in space can occur in multiple stages along the contruction process ( $\mathrm{Wu} \& \mathrm{Cu}, 2010) \&(\mathrm{~N}$. Pradhananga\& J. Teizer, 2014) explained that congestion analysis in site arrangement space planning depends on space limitations and resource movement in the construction site itself. Congestion potential can be determined before the implementation of construction site arrangement and comparing alternative site arrangement designs (N. Pradhananga \& J. Teizer, 2014).

Constructing Excellence (2004) have recorded that effective logistic system is achieved by reducing the movement of vehiecle to the site. All of the effects have to be considered when evaluating the strategies to reduce congestion (Todd Litman, 2013). Furthermore, storage space is categorized as a flexible workspace but not all because the resource space transition will be determined by the characteristics of the material itself (Semenov V. et al., 2014). However, material resource design can be arranged according to the management and material resource storage location which changes according to the reviewed schedule. In the event when space conflict can be solved with changing workspace location, there is no effective impact on the schedule and the congestion that occured (M. Kassem et al., 2015). According to the conflict resolution and workspace congestion by R. D. Chavada (2012), final workspace management process is when previous data is used to solve the conflict. Zhang et al. (2015) also stated that there ia need to collect, formalize and reuse the workspace information of the previous activities.

This study explains the generation of congestion index of construction by measuring the characteristics of site congestion that happened due to the management of resource storage.Moreover, the study also produced congestion index according to resource storage in project site. 
The main aim is to ensure that congestion in construction site due inadequate and disordered resource storage will not happen. It is necessary to study the characteritics of site congestion to identify the source of the problem in the event of congestion in construction. Later, the study focused on resource storage space to suggest a method to calculate the congestion index in construction. This study also took into account the workspace congestion namely the whole space not the building. The main issue is to improve the management of efficient resource storage in limited construction site and to ensure no critical congestion will happen during construction operation.

\section{DETERMINATION INDEX OF CONSTRUCTION SITE CONGESTION}

\subsection{Characteristics of Construction Site Congestion}

The characteristics of congestion have to be detailed out before the solution method is choosen as to effectively tackled the problem of the congestion. According to previous studies, there are four main categories of congestion chracteristics identified namely limited space, weak site productivity, impaired construction site safety and inorganized system. Basically, construction with unplanned space acpects will induce difficulties to evaluate and to deliver schedule (Rajiv Chavada et al., 2011). Congestion can also occur due to schedule conflict which hideres the movement of project activities (N. R. Esfahan \& S. Razavi, 2015). Hansson \&Hedberg (2015) have agreed that insufficient space in construction is a normal problem faced when running a construction in town areas. Small space for equipment, limited workspace and narrow access space are the indication towards the level of congestion at construction site (Mortaheb et al., 2007). Spillane et al. (2017) have defined limited space construction site as site with building area of more than $90 \%$ of the whole construction site area within the boundaries of the site.

Moreover, according to Pande\&Sabihuddin (2015), many studies and reports stated that the lack of efficiency and productivity in construction industry in delivering resource movement and equipment management at a precise period. This issue can be associated with site congestion when resource transfer is not managed efficiently at the site will cause the productivity in the work process to worsen and low in quality. Besides that, Gore et al. (2012) also stated that congested construction site planning will give a negative impact construction safety and its performance. According to Spillane et al. (2014), the need of sufficient planning is important to avoid excessive movement of resources at a construction site and the probability of multiple resource handling will cause site congestion. In addition, the works of Patel \&Vyaas (2011) also stated that managing and controlling resource effectively with measuring resource management performance by evaluating its effectiveness can produce a different result. One of the causes of vague and disordered system is the lack of communication and responsibility between the associated party. This issue always happens in congested construction site where it can cause difficulties at multiple communication levels. Table 1 below showed characteristics of construction site congestion identified according to previous studies as a data to be tested in this study.

Table 1 Characteristics of site congestion based on previous study

\begin{tabular}{|c|c|c|}
\hline Item & $\begin{array}{c}\text { Characteristics of site } \\
\text { congestion }\end{array}$ & $\begin{array}{l}\text { Previous study } \\
\text { references }\end{array}$ \\
\hline $\mathrm{C} 1$ & $\begin{array}{l}\text { Narrow workplace of } \\
\text { construction } \\
\text { operations }\end{array}$ & $\begin{array}{l}\text { Spillane et al. (2014), } \\
\text { Hansson \&Hedberg } \\
\text { (2015), Said \& El-Rayes } \\
(2012)\end{array}$ \\
\hline $\mathrm{C} 2$ & $\begin{array}{l}\text { Unwanted construction } \\
\text { resource at site }\end{array}$ & $\begin{array}{l}\text { Spillane et al. (2014), } \\
\text { Adewuyi\&Odesola } \\
(2015) \text {, Liwan (2015) }\end{array}$ \\
\hline C3 & $\begin{array}{l}\text { The transfer of non- } \\
\text { critical activities in the } \\
\text { operations workplace }\end{array}$ & $\begin{array}{l}\text { Mortaheb et al. (2007), } \\
\text { Said \& El-Rayes (2012) }\end{array}$ \\
\hline $\mathrm{C} 4$ & $\begin{array}{l}\text { The flow of resource } \\
\text { and equipment not } \\
\text { according to the right } \\
\text { time }\end{array}$ & $\begin{array}{l}\text { Spillane et al. (2014), M. } \\
\text { Kassem et al. (2015), } \\
\text { Spillane et al. (2013), } \\
\text { Mortaheb et al. (2007), } \\
\text { Hansson } \\
\text { (2015) }\end{array}$ \\
\hline
\end{tabular}

C5 Construction site access is not suitable

Marcom Group Ltd. (2015), Spillane et. al. (2013), Spillane et al. (2014), Liwan (2015)

C6 Large scale projects causing work operations to occur at the same time

C7 Excessive resource movement at construction site

C8 Delay or changes in construction material production schedule

C9 Workplace conflict verification process is inefficient

R. D. Chavada et al. (2012), Mortaheb et al. (2007)

Spillane et al. (2013), R D. Chavada et al. (2012)

M. Kassem et al. (2015), Spillane et. al. (2013), Ahmed (2017)

M. Kassem et al. (2015), R. D. Chavada et al. (2012), Patel \&Vyaas (2011)

C10 Construction project Spillane \&Oyedele areas in congested areas (2013), Hansson (cities)

\&Hedberg (2015)

Pinfold \&Fapohunda (2015)

C11 No detailed planning for N. Pradhananga\& J. the space before Teizer (2014), construction begins Arijeloye\&Akinradewo (2016)

C12 No room for long term Spillane et al. (2014), storage of material $\quad$ Said \&Rayes (2012)

\subsection{Strategy of Material Storage on Site Congestion}

Acquisition and storage of materials at construction sites should be carefully planned and implemented to avoid the negative effects of material deficiencies or excessiveness at the site (Said \& El-Rayes, 2011) 
ByungjooChoil et al. (2014) stated that in the case of storage space, the type of motion-based workspace can be determined by material characteristics while storage space is generated at the beginning of the activity and at the end of the activity. The level of identification of workplace requirements is the process of identifying the entire workplace and storage space requirements for the execution of specific activities (ByungjooChoil et al., 2014). In the study by C. Huang et al. (2010) said that when limited space is available on the construction site, inadequate storage space in multi-storey building construction site can be tackeled after constructing the basement floor and sufficient structural strength have been built. It can be used to store temporary building materials to reduce material transport time and improve overall construction efficiency.

\subsection{Index of Congestion by Characteristics}

This study has created a developed site congestion questionnaire as one of the methods for obtaining the congestion index. In addition, the distribution of congestion assessment forms is carried out of in which the parties involved in the construction of the project site are the respondent. Example of question: "In your observation, does the site of this project suffered critical congestion?" [ $1=$ strongly disagree, $2=$ disagree, $3=$ not sure, $4=$ agree, $5=$ strongly agree]. Calculations using Relative Importance Index (RII) is as follow:

$$
\frac{\sum W}{A N}=\frac{5 n_{5}+4 n_{4}+3 n_{3}+2 n_{2}+1 n_{1}}{5 N} \pi r^{2}
$$

Where $w$ is weight given to each factor by respondents (1-5), $n_{l}$ is the number of respondents who responded "not important"; $n_{2}$ is the number of respondents who choose "slightly important"; $n_{3}$ is the number of respondents who choose "fairly important"; $n_{4}$ is the number of respondents who choose "important"; and $n_{5}$ is the number of respondents who choose "very important" (Enshassi et al. 2007). $A$ is the higest weight (which is 5 in the study) and $N$ is the total sample. The relative importanc index rangers between 0 to 1 (Naoum, 2007). The example of scale index Hwang et al. (2013)\&Holt (2014) of RII is from 0.143 to 1 (higher values than RII indicating the higher impact of this factor). Besides that Aghili et al. (2019) have categorized three important levels which is high $(\mathrm{H})(0.8 \leq \mathrm{RII} \leq 1)$, medium $(\mathrm{M})(0.5 \leq$ $\mathrm{RII} \leq 0.8)$ and low (L) $(0 \leq \mathrm{RII} \leq 0.5)$, however, used medium (M) method in the study. The RII values ranges between 0 to 1 (not including 0 ) where at higher RII, the importance of the factor is higher.

Having identified several scales in the implementation of the relative importance index, this study has chosen to use
RII values derived from survey data conducted to obtain index scales and site congestion levels based on congestion characteristics. The higher the value of RII and its importance, the higher the level of congestion for these characteristic items. The importance status is determined based on the index range, which is RII value of $0.0-0.6$ (low importance/ low congestion level), $0.6-0.8$ (medium importance/ medium congestion level) dan $0.8-1.0$ (high importance/ high congestion level).

\subsection{Index of Congestion by Construction Area}

This study used building site measurement as a method of obtaining data to generate a site congestion index. This study has calculated non-building coverage ratio (NBCR) by using site measurement datas which is the project site area and building site area. Then, the hypothesis is based on the results of the calculations were performed. The initial hypothesis was that low NBCR values showed high congestion whereas high NBCR values were low congestion.

NBCR index values less than or equal to 0.5 represent high congestion and NBCR greater than 0.6 represent low congestion whereas NBCR values between 0.5 and 0.6 represent moderate congestion. This scale was generated based on the obtained NBCR values. Turning to the NBCR used in this calculation method, the researchers used this conclusion as it was closer to the objective of this study. Generally, this NBCR formula is derived from the BCR formula (building coverage ratio) which is used to obtain building coverage density (İsmail Büyüksalih, 2016), E. Bratsolis et al. (2016) \& T. Megayanti et al. (2018). The study has applied the BCR formula according to the suitability of the study variables and produced the NBCR. The summary of the non-building coverage ratios used in this study (NBCR) is:

$$
\begin{aligned}
& \mathrm{NBCR}=\mathrm{S}_{\mathrm{NB}} / \mathrm{S}_{\mathrm{L}} \\
& \mathrm{S}_{\mathrm{NB}}=\mathrm{S}_{\mathrm{L}}-\mathrm{S}
\end{aligned}
$$

Where $S_{N B}$ is the value of non-building area, $S_{L}$ is the total area of the whole site, $S$ is the value of area of building. The building area is usually in the early stages of construction after the ground work is carried out, the building site will start the pile installation operation and so on. Therefore, this non-building area will serve as a storage space on the site. Researchers are studying whether the level of congestion can affect the storage of materials on site. Figure 1 below showed one of the site plans that has been tested in terms of site congestion index value which is ResidensiRampai 2. 


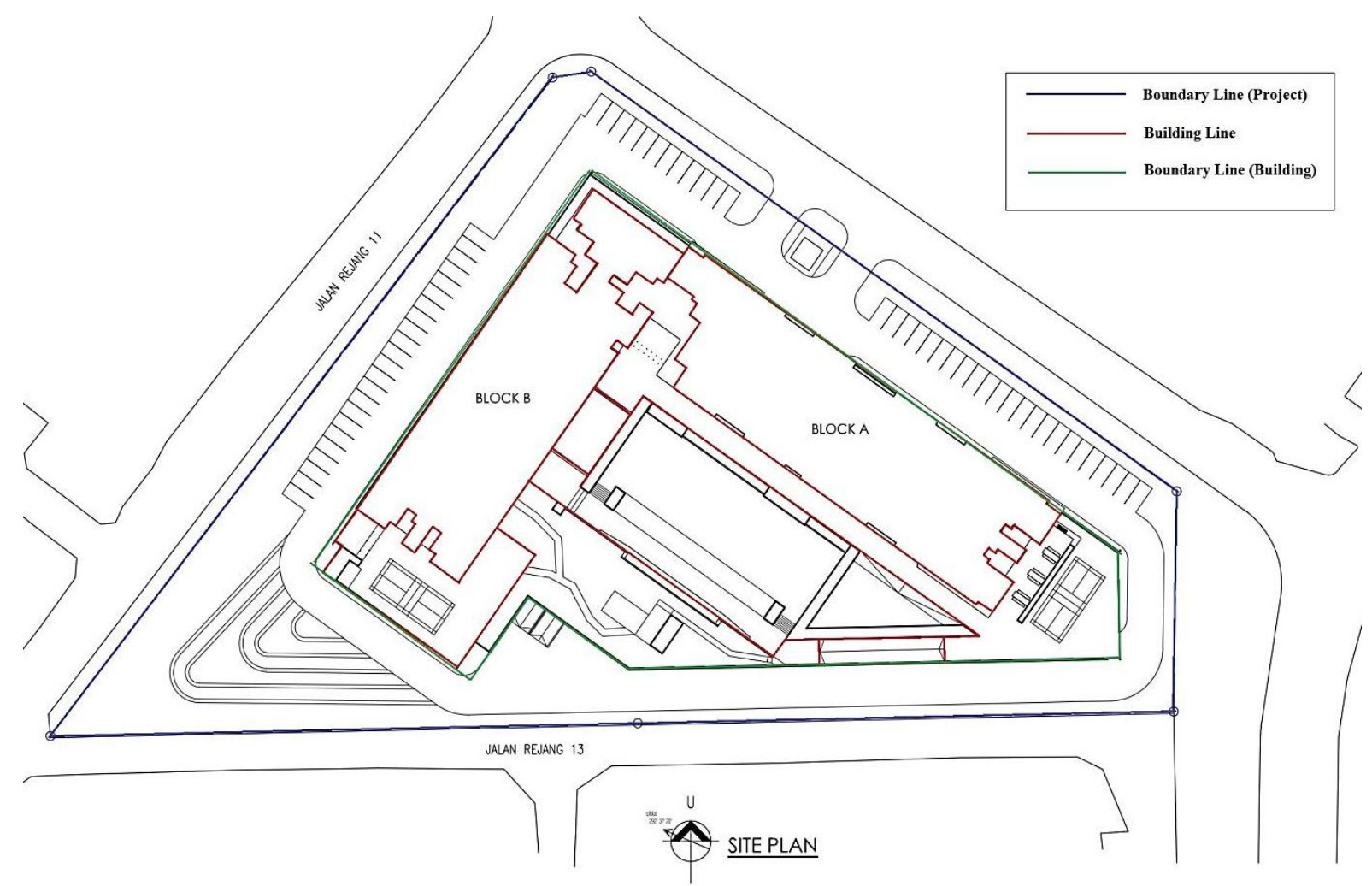

Figure 1 Site plan of ResidensiRampai 2

III. METHODOLOGY

Figure 2 below showed step by step process of generating site congestion index conducted in this study.

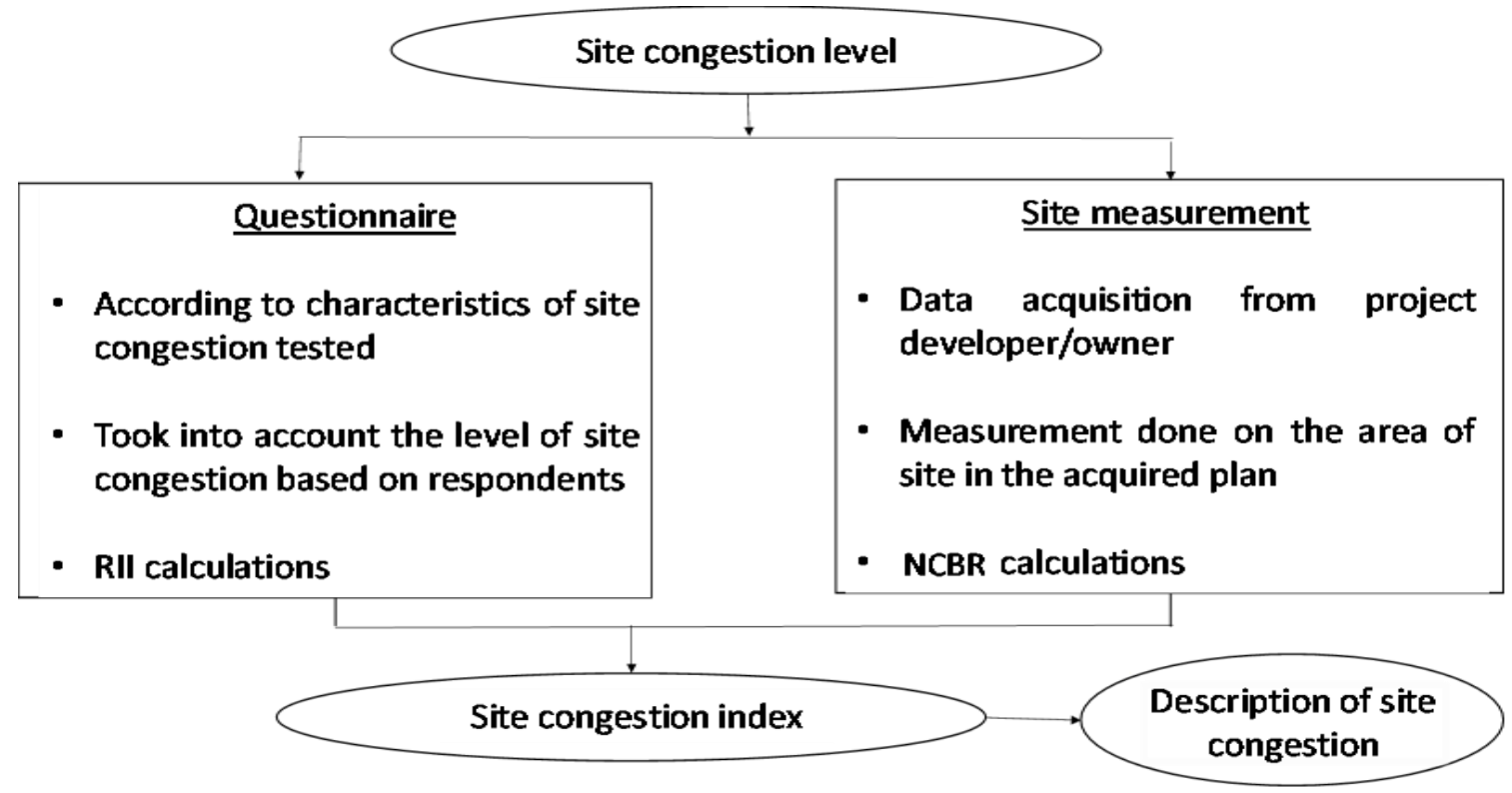

Figure 2 Process of generating site congestion index

\subsection{Participants}

Among the positions considered in this study were $26.9 \%$ material manager, $30.3 \%$ site engineer, $6.5 \%$ site supervisor, $15.9 \%$ civil engineer, $2.5 \%$ MEP engineer, architect, material surveyor and others were $1.5 \%$ and $15.9 \%$, respectively. Site measurements were performed to determine the total area of the site and the total area of the project building through the site plan provided by the project developer themselves where first, the study re-tested the values of the area in the site measurement method and, second, generated a site congestion index. This study selected the construction type of residential complex in Kuala Lumpur. The data were extracted from the CIDB 2017 construction records for the quarter of June 2017 which recorded 28 sites. Of the total, only 16 sites were identified and cooperated in providing the project information needed in this study. 


\subsection{Site Measurement Procedure}

The variables that were measured are the size or overall size of the construction site and the area of the site used. The developers have provided the site plan drawings in which the plan is in .pdf format. Then, the drawing file was opened in Adobe Acrobat Professional v7.0 software. This software is a simple tool that can be used to find out the overall area and length of a building. The steps to use to measure the area of a site using this software are as follows:

i. See the scale of the drawing to find out how to convert it to a scale manually to determine which unit to use for measurement.

ii. Select the tools button ('Tools'), measurement ('Measuring'), and then select area tool ('Area Tool'). When drawing is ready to measure space, the dimensions need to be selected accurately.

iii. Select the first point of the breadth measurement and the next point, then make sure the point meets again at the first point. Save and record the width of the displayed area. All site plans undergo the same steps to obtain the total site area and building area.

Measurement results indicated the total area of the project site (within the boundary) and the total area of the building where the comparison between these values and the area value has been given by the project developer. This is because the study needs to validate the data received to ensure that this study uses valid data to produce a justifiable study.

\section{RESULTS AND DISCUSSION}

Site congestion is a factor that is tested in this research. At the end of this analysis, the two index values of these two methods cannot be directly compared because of the differences in the factors tested but can still be discussed to get the hypotheses of the results of this study as well as their advantages in efficient building resource management. This is because site congestion information needs to be reviewed early by construction management so that the material storage process has its own goals.

\subsection{Site Congestion of Questionnaire Surveys}

Data analysis of the questionnaire method was performed using the Relative Important Index (RII) formula, and then the results of this index formed the scale of the index that was measured based on the index range itself. A total of 201 respondents who answered the site's congestion questionnaire formed strong data for analysis. The study conducted the validity and reliability test of the data used with Cronbach's Alpha test, and yielded a value that meets the allowable reliability level of 0.780 . Figure 3 is the result of RII value based on the level of congestion of the respondents' project site. The results recorded the highest level of project site congestion where 80 respondents stated that their project site had normal congestion. The definition of a site with normal congestion as described in this survey is that the estimated area of non-building space is the same as that of the entire construction site. This can also be considered as the critical congestion that occurs at the construction site is likely to be low.

However, the second highest level of congestion recorded 76 respondents experiencing a tight project site, with a percentage of total non-building space being $30 \%$ compared to $70 \%$ of the overall construction site. It has been noted that a number of these sites need to be taken into account to identify the cause of the congestion so that no critical congestion occurs in the future. Only 9 respondents recorded levels of extreme congestion to represent their projects. This requires careful planning because limited space to share includes materials storage space, machinery space, temporary offices and more. The overall value of the index of interest was recorded at 0.5493 .

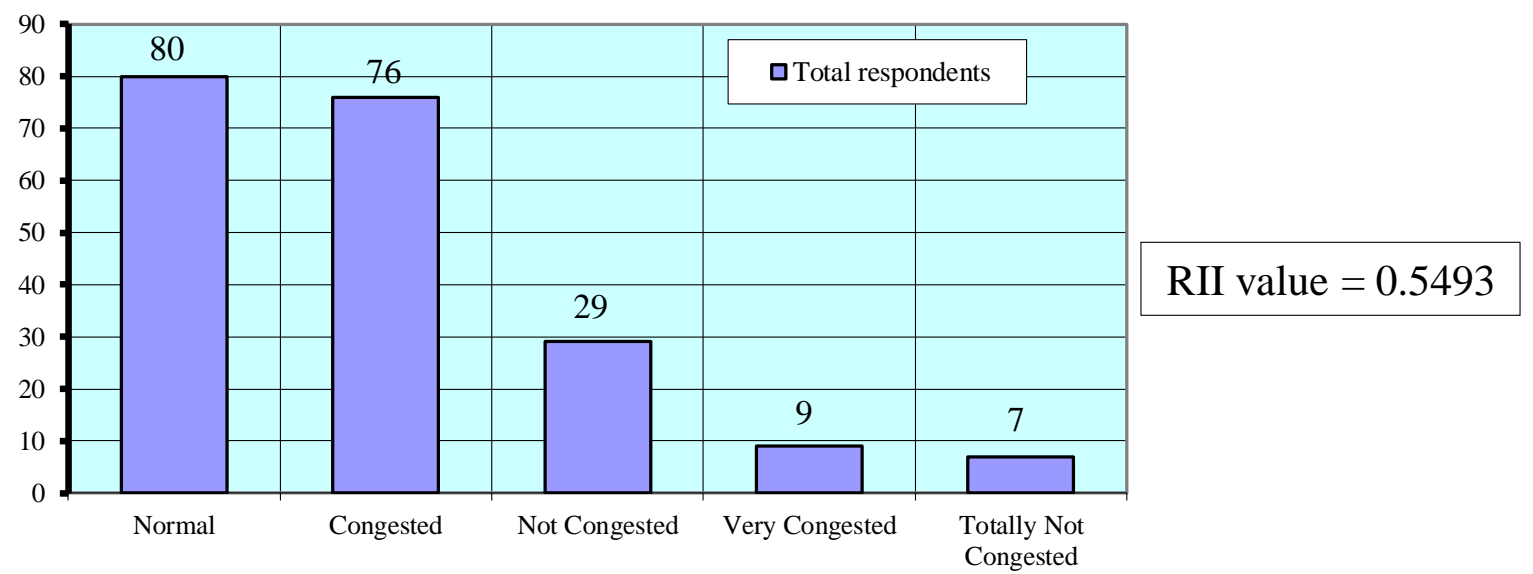

Figure 3 RII value of project site congestion level

The results of the RII values based on the 12 site congestion characteristics are all listed in Table 2. The highest RII value among the 12 site congestion characteristics is 0.8557 which is the characteristic of 'delay or change in construction material production schedule'. Respondents have been responding to this type of congestion characteristic where changes to the schedule will result in some other material planning changes leading to project delays. Management needs to acknowledge what the issue is, including initial design validation, on-site work performance and material requirements verification. This is because there are construction sites that experience congestion when site activities overlap and the differences

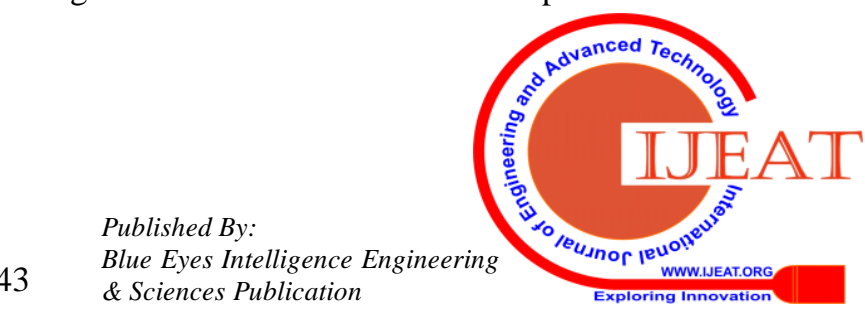


in building materials requirements. Material production schedules should be consistent with planning during construction work activities so that the necessary materials are available when needed.

The congestion characteristic for construction project areas in congested areas such as the city shows a very high RII value of 0.8498 . This proves that the area around the project site also affects the congestion in the construction site. This is due to the limited area of the project site and the construction of the concentrated area affecting the congestion of the site. In addition, the materials brought in should also be controlled to prevent this characteristic of congestion at the project site and to allow the remaining space to be used for other uses. Additionally, the inefficiency of the workplace conflict verification process is one of the characteristics of congestion which has a high RII value of 0.8219 .

Table 2 RII values of different characteristics of site congestion

\begin{tabular}{|c|c|c|c|}
\hline Item & $\begin{array}{c}\text { Characteristics of site } \\
\text { congestion }\end{array}$ & $\begin{array}{c}\text { RII } \\
\text { value }\end{array}$ & $\begin{array}{c}\text { Congestion } \\
\text { level }\end{array}$ \\
\hline $\mathrm{C} 1$ & $\begin{array}{lr}\text { Narrow workplace } & \text { of } \\
\text { construction } & \text { site } \\
\text { operations } & \end{array}$ & 0.8199 & High \\
\hline $\mathrm{C} 2$ & $\begin{array}{l}\text { Unwanted construction } \\
\text { resource at site }\end{array}$ & 0.6398 & Medium \\
\hline C3 & $\begin{array}{l}\text { The transfer of non- } \\
\text { critical activities in the } \\
\text { operations workplace. }\end{array}$ & 0.6806 & Medium \\
\hline $\mathrm{C} 4$ & $\begin{array}{l}\text { The flow of resource and } \\
\text { equipment not according } \\
\text { to the right time. }\end{array}$ & 0.7612 & Medium \\
\hline C5 & $\begin{array}{l}\text { Construction site access } \\
\text { is not suitable }\end{array}$ & 0.6438 & Medium \\
\hline C6 & $\begin{array}{l}\text { Large scale projects } \\
\text { causing work operations } \\
\text { to occur at the same time }\end{array}$ & 0.6677 & Medium \\
\hline C7 & $\begin{array}{l}\text { Excessive resource } \\
\text { movement at construction } \\
\text { site }\end{array}$ & 0.7572 & Medium \\
\hline $\mathrm{C} 8$ & $\begin{array}{l}\text { Delay or changes in } \\
\text { construction material } \\
\text { production schedule }\end{array}$ & 0.8557 & High \\
\hline C9 & $\begin{array}{l}\text { Workplace } \\
\text { verification process is } \\
\text { inefficient }\end{array}$ & 0.8219 & High \\
\hline $\mathrm{C} 10$ & $\begin{array}{l}\text { Construction project areas } \\
\text { in congested areas (cities) }\end{array}$ & 0.8498 & High \\
\hline C11 & $\begin{array}{l}\text { No detailed planning for } \\
\text { the space before } \\
\text { construction begins }\end{array}$ & 0.5940 & Low \\
\hline $\mathrm{C} 12$ & $\begin{array}{l}\text { No room for long term } \\
\text { storage of material }\end{array}$ & 0.7910 & Medium \\
\hline
\end{tabular}

Workplace conflict is a planning for workspace on a problematic construction site. Issues such as accidents, construction work errors and inconvenient weather are among the workplace conflicts that need to be addressed early on by management so that construction activities do not need to be delayed and the required workspace cannot be utilized. Workplaces also include materials storage areas and machinery main routes. Based on the other characteristics of the congestion, the lowest RII values accounted for the features of no planned planning of the space before construction began. This is not a common feature of congestion at the project site as most project site planning fluctuates according to the situation especially for crowded construction site space. Initial planning of space restructuring is impractical for some contractors as there will be changes taking place based on the construction stage. Here it can be argued that construction sites with critical congestion need to take precautionary measures, management needs to know the level of site congestion up to the construction stage and until the project is completed to streamline site storage process in an efficient manner. Based on the results described, it can be concluded that each level of site congestion has a category of congestion characteristics and includes actionable solutions.

\subsection{Site Congestion of Site Measurement}

Site measurement is to obtain the non-building coverage ratio (NBCR) as site congestion index calculation. The size of the non-building area in question is a space that can be used by the contractor other than the building space. This index calculation has been tested for the range of congestion indices and can determine the status of the site congestion levels studied. Table 3 showed the NBCR values for the 16 project sites where the lower NBCR values show higher site congestion. In addition, the higher the value of the nonbuilding site would translate to the lower the congestion rate as the larger area will indicate more space for contractors and management to use as storage facilities, temporary offices, machinery storage and so on.

Residensi Kepongmas project has recorded the lowest percentage of NBCR values among other project sites which is 0.37 with the value of total area of $6,241.74$ $\mathrm{m}^{2}$. This is because the total area of building exceesds $60.0 \%$ of the overall area which also proves that the nonbuilding space is low and the project site can be considered congested. Compared to the project site with the largest total area is the Residenci Pandanmas project which is 34,038.27 $\mathrm{m}^{2}$ but the building area of $52.50 \%$ of the total proves the remaining percentage is non-building space. In this case, the construction site may be considered as overcrowded or moderately crowded as the percentage of building area and open space is slightly different. 
Table 3 Results of NBCR values

\begin{tabular}{|c|c|c|c|c|}
\hline Project Name & $\begin{array}{l}\text { Total Overall Site } \\
\text { Area }\left(S_{L}\right), \mathbf{m}^{2}\end{array}$ & $\begin{array}{l}\text { Total Building } \\
\text { Area }(\mathbf{S}), \mathbf{m}^{2}\end{array}$ & $\begin{array}{l}\text { Total Non-building } \\
\text { Area }\left(\mathrm{S}_{\mathrm{NB}}\right), \mathbf{m}^{2}\end{array}$ & NBCR \\
\hline ResidensiWangsaMeranti & $2,807.32$ & 955.71 & $1,851.61$ & 0.66 \\
\hline Residensi Seri Wahyu & $6,968.51$ & $2,024.72$ & $4,943.79$ & 0.71 \\
\hline ResidensiLaman Sari & $16,848.19$ & $8,986.26$ & $7,861.93$ & 0.47 \\
\hline ResidensiKepongmas & $17,074.59$ & $10,832.85$ & $6,241.74$ & 0.37 \\
\hline ResidensiPuchongmas & $7,132.17$ & $2,939.93$ & $4,192.24$ & 0.59 \\
\hline ResidensiPandanmas & $34,038.27$ & $16,170.88$ & $17,867.39$ & 0.52 \\
\hline Vista Langkawi@Residensi PV18 & $23,942.33$ & $14,512.18$ & $9,430.15$ & 0.39 \\
\hline ResidensiDesamas & $4,118.32$ & $1,337.53$ & $2,780.79$ & 0.68 \\
\hline ResidensiEnesta Kepong & $17,526.22$ & $5,460.35$ & $12,065.87$ & 0.69 \\
\hline Residensi Lanai Bukit Jalil & $9,864.43$ & $2,642.87$ & $7,221.56$ & 0.73 \\
\hline ResidensiRimbunanPetaling & $11,767.25$ & $3,897.13$ & $7,870.12$ & 0.67 \\
\hline ResidensiRampai 2 & $12,460.13$ & $7,336.50$ & $5,123.63$ & 0.41 \\
\hline ResidensiTasikmas & $19,437.25$ & $6,903.50$ & $12,533.75$ & 0.64 \\
\hline ResidensiSelayangDamai & $5,068.67$ & $1,413.70$ & $3,654.97$ & 0.72 \\
\hline ResidensiSkyAwani 3 & $17,373.28$ & $6,186.30$ & $11,186.98$ & 0.64 \\
\hline ResidensiDesaSatumas & $31,794.28$ & $11,862.90$ & $19,931.38$ & 0.63 \\
\hline
\end{tabular}

Table Error! No text of specified style in document.Status of congestion index

\begin{tabular}{|c|c|c|}
\hline Project Name & Index Range & $\begin{array}{c}\text { Index } \\
\text { Status }\end{array}$ \\
\hline ResidensiWangsaMeranti & $\mathrm{NBCR}>0.6$ & Low \\
\hline Residensi Seri Wahyu & $\mathrm{NBCR}>0.6$ & Low \\
\hline ResidensiLaman Sari & $\mathrm{NBCR}<=0.5$ & High \\
\hline ResidensiKepongmas & $\mathrm{NBCR}<=0.5$ & High \\
\hline ResidensiPuchongmas & $\begin{array}{c}0.5<\mathrm{NBCR}> \\
0.6\end{array}$ & Medium \\
\hline ResidensiPandanmas & $\begin{array}{c}0.5<\mathrm{NBCR}> \\
0.6\end{array}$ & Medium \\
\hline Vista Langkawi @ & $\mathrm{NBCR}<=0.5$ & High \\
\hline Residensi PV18 & & \\
\hline ResidensiDesamas & $\mathrm{NBCR}>0.6$ & Low \\
\hline ResidensiEnesta Kepong & $\mathrm{NBCR}>0.6$ & Low \\
\hline Residensi Lanai Bukit Jalil & $\mathrm{NBCR}>0.6$ & Low \\
\hline $\begin{array}{l}\text { ResidensiRimbunanPetalin } \\
\mathrm{g}\end{array}$ & $\mathrm{NBCR}>0.6$ & Low \\
\hline ResidensiRampai 2 & $\mathrm{NBCR}<=0.5$ & High \\
\hline ResidensiTasikmas & NBCR >0.6 & Low \\
\hline ResidensiSelayangDamai & NBCR $>0.6$ & Low \\
\hline ResidensiSkyAwani 3 & NBCR $>0.6$ & Low \\
\hline ResidensiDesaSatumas & NBCR $>0.6$ & Low \\
\hline
\end{tabular}

Then, the study categorized the NBCR values into three stages of the site congestion index to label the congestion level of each project site as shown in Table 4. The results showed that there are 3 sites with high congestion levels with less than or equal to 0.5 which are ResidensiKepongmas, Residensi PV18 and ResidensiRampai 2 projects. In overall, most of the project sites surveyed had moderate to low congestion levels. This also proves that, at present, many high-rise residential types have been designed with strategic building space area and non-building areas especially in urban areas such as Kuala Lumpur. Building design in the land area has an importance in the process of construction management. This is because crowded sites can cause a number of other factors to affect and may slow down the performance of construction work. However, the study conducted interviews with certain hightraffic congestion sites where they were generally admitted to be congested for a period of time involving a variety of critical activities simultaneously. Therefore, knowing the site congestion index can efficiently analyze site management strategies including building materials management.

In conclusion, after the analysis was conducted to generate a site congestion index for two methods, questionnaire analysis and site measurement, two conclusions were based on the results. The congestion level index for the questionnaire method performed by analyzing the data obtained using the RII formula has produced an index range based on the congestion characteristics of the project site. A high RII value indicates a higher level of site congestion based on these characteristics. A total of 201 respondents provided feedback on site congestion features that represented the project they were working on. The index range for this method is $<0.70$ representing the low congestion level index, the 0.70 to 0.80 index range is the medium high congestion level index while values above $80.0 \%$ are the high congestion index. There are 4 site congestion features that show RII value readings with a high level of site congestion indexes, such as "Narrow workplace of construction site operations", "Delays or changes in construction material production schedule", "Workplace conflict verification process is inefficient", and " Construction project areas in congested areas (cities) ". Based on these 4 features it can be concluded that these features should be focused on site management as a preliminary action and risk preparation practice. Every construction project has a level of risk that needs to be addressed but knowing the features that can increase the congestion can make it easier for stakeholders to plan their construction project carefully. 
Furthermore, the congestion level index based on the site measurement method can be parsed with a range of NBCR indices $\leq 0.5$ representing high congestion level indices, 0.5 $<$ NBCR > 0.6 are medium congestion level indices and $\mathrm{NBCR} \geq 0.6$ are low congestion level indices. Compared to the index range based on the high RII congestion characteristics, the high congestion rate is the opposite of the one based on site-based measurements where low NBCR values represent high congestion. Table 4 lists 3 project sites with high congestion levels, namely Residensi Kepongmas, Vista Langkawi@ Residensi PV18 and Residensi Rampai 2. An average of 16 measured sites depict low and medium congestion levels which prove most project sites the multistorey home in Kuala Lumpur has successfully dealt with the issue of frequent congestion. However, there is still a lot of practice that needs to be implemented in the efficient management of material storage because congestion at the construction site can be attributed to various factors.

\section{CONCLUSION}

The level of site congestion in the study was determined by conducting two research methods - questionnaire and project site survey. The calculated index of the survey data method can serve as a guide for management to identify possible congestion characteristics at the project site. In addition, it can also identify actions that can be taken when the project site is in a state of congestion based on the suitability of the project site and the characteristics of the congestion. Based on the scale of the index, the four features with the highest RII values are characteristic of congested construction sites. On a project site that is experiencing situations such as these features it is necessary to take precautionary steps to avoid critical issues that will jeopardize construction productivity.

Continuing with the site measurement study, the results for the low-value NBCR percentages indicate a high level of site congestion. Index scale is determined by the resulting NBCR value. The NBCR results show an overall average of 0.60 . Then, the study categorized the NBCR values into three ranges of site congestion levels to label the congestion levels of each project site studied. The results show that there are 3 sites with high levels of congestion with a range of less than 0.5 namely the Residensi Kepongmas, Residensi PV18 and Residensi Rampai 2. Overall, the average NBCR percentage value for all project sites indicates that the project site under review has a moderate to low congestion. This also proves that at present many high-rise residential types have been designed with the breadth of building sites and open spaces strategically placed in urban areas such as Kuala Lumpur. This is because congested sites can cause a number of other factors to affect and may slow down the performance of the construction work as well as affect the project's success factors, cost, time and quality. Therefore, knowing the site congestion index can efficiently analyze site management strategies including building materials management. In addition material management can create a more organized site schedule.

\section{DATA AVAILABILITY}

All data, models, or codes generated or used during the study are available from the corresponding author by request.

\section{ACKNOWLEDGMENT}

This research paper is based upon work supported by the UniversitiKebangsaan Malaysia and Ministry of Education Malaysia under Grant No. GGPM-2017-058 and FRGS/1/2017/SS03/UKM/03/1.

\section{REFERENCES}

1. Adewuyi T. \&Odesola, I. 2015. Factors affecting material waste on construction sites in Nigeria. Journal of Engineering and Technology factors, 6(1), 82-99.

2. Aghili, N., Hosseini, S. E., Bin Mohammed, A. H. \&ZainulAbidin, N. 2019. Management criteria for green building in Malaysia; relative important index. Energy Sources, Part A: Recovery, Utilization and Environmental Effects, 1-15.

3. Ahmed, Z. 2017. The impact of material management on construction project delivery in Maldives. UniversitiTunku Abdul Rahman.

4. Arijeloye B. T. \&Akinradewo F. O. 2016. Assessment of materials management on building projects in Ondo State, Nigeria. WSN World Scientific News, 55(55), 168-185.

5. Bratsolis, E., Charou, E., Tsenoglou, T. \&Vassilas, N. 2016. Automated building block extraction and building density classification using aerial imagery and LiDAR data. Journal of Earth Science and Engineering, 6(1), 19 .

6. Büyüksalih, İ. 2016. Building zone regulation compliance using LIDAR data: Real-life tests in İstanbul. International Journal of Environment and Geoinformatics, 3(1), 48-55.

7. ByungjooChoil, Hyun-Soo Lee, Moonseo Park, Yong K. Cho \&Hyunsoo Kim. 2014. Framework for work-space planning using four-dimensional BIM in construction projects. Journal of Construction Engineering and Management, 140.

8. C. Huang, C. K. Wong \& C. M. Tam. 2010 Optimization of material hoisting operations and storage locations in multi-storey building construction by mixedinteger programming. Automation in Construction, 19, 656-663.

9. Dennis Lenard. 2004. Construction logistics. Constructing Excellence, 19.

10. Enshassi, A., Mohamed, S. \& Mayer, P. E. 2007. Factors affecting labour productivity in building projects in the Gaza strip. Journal of Civil Engineering and Management, 13(4), 245-254.

11. Gore, S., Song, L. \&Eldin, N. 2012. Photo-modeling for construction site spacing planning.

12. Hansson, M. \&Hedberg, N. 2015. Construction logistics from a subcontractor perspective A case study of a congested construction site. Master of Science Thesis in the Design and Construction Project Management Programme. Chalmers University of Technology. Hisham Said \&Khaled El-Rayes. 2011. Optimizing material procurement and storage on construction sites. Journal of Construction Engineering and Management, 137, 421-431. 
13. Holt, G. D. 2014. Asking questions, analysing answers: Relative importance revisited. Construction Innovation, 14(1), 2-16.

14. Hwang, B. G., Zhao, X. \& Ng, S. Y. 2013. Identifying the critical factors affecting schedule performance of public housing projects. Habitat International, 38, 214221.

15. I-Chen $\mathrm{Wu} \&$ Yen-Chang Chiu. 2010. 4D workspace conflict detection and analysis system. 10th International Conference on Construction Applications of Virtual Reality.

16. Kaiman Li, HanbinLuo, \&Mirosław J. Skibniewskic. 2019. A non-centralized adaptive method for dynamic planning of construction components storage areas. Advanced Engineering Informatics, 39, 80-94.

17. Liwan, S. R. 2015. The Framework of Improving On-site Materials Tracking for Inventory Management Process in Contruction Projects.

18. M. Kassem, N. Dawood\& R. Chavada. 2015. Construction workspace management within an Industry Foundation Class-Compliant 4D tool. Automation in Construction, 52, 42-58.

19. Megayanti, T., Widaningsih, L., Minggra, R. \&Dewi, N. I. K. 2018. Building coverage ratio at the eastern corridor of Jalan Ir. H. Djuanda Bandung. IOP Conference Series: Materials Science and Engineering, 288.

20. Mortaheb, M. M., Dehghan, R., Ruwanpura, J. Y. \&Khoramshahi, F. 2007. Major factors influencing construction productivity in industrial congested sites. CSCE 2007 Annual General Meeting \& Conference, $1111-1120$

21. N. Pradhananga\& J. Teizer. 2014. Congestion analysis for construction site layout planning using real-time data and cell-based simulation model. Computing in Civil and Building Engineering, 681-688.

22. Naoum, S. G. 2007. Dissertation research \& writing for construction students.

23. NazilaRoofigari Esfahan \&SaiedehRazavi. 2015. Optimizing linear schedules: congestion-minimization approach. 5th International/11th Construction Specialty Conference, 125, 1-10.

24. Pande, A. A. \&Sabihuddin, S. 2015. Study of material management techniques on construction project. International Journal of Informative \& Futuristic Research (IJIFR), 2(9), 3479-3486.

25. Patel, K. V. \&Vyaas, C. M. 2011. Construction materials management on project sites. National Conference on Recent Trends in Engineering \& Technology.

26. Pinfold L. \&Fapohunda J. A. 2015. Using location awareness technologies for innovative construction management in urban centres: Study of the CBD, Cape Town, SA. Geospatial World Forum.

27. Qiankun Wang, ZengGuo, Tingting Mei, Qianyao Li \&Peng Li. 2018. Labor crew workspace analysis for prefabricated assemblies' installation: a 4D-BIM-based approach. Engineering, Construction and Architectural Management.

28. R. D. Chavada, M. Kassem, N.N. Dawood\& K. K. Naji. 2012. Framework for construction workspace management a serious game engine approach. Computing in Civil Engineering, 57-64.

29. R. Jongeling, J. Kim, M. Fischer, C. Mourgues\& T. Olofsson. 2008. Quantitative analysis of workflow, temporary structure usage, and productivity using $4 \mathrm{~d}$ models, Autom. Constr., 17 (6), 780-791.

30. Rajiv Chavada, NashwanDawood\&MohamadKassem. 2011. Construction workspace management: the development and application of a novel $\mathrm{nD}$ planning approach and tool. ITcon ,17, 213.

31. S.P. Dozzi, P.Eng. \& S.M. AbouRizk. 1993. Productivity in construction. NRCC-37001.
32. Semenov V., Anton Anichkin A., Morozov S., Tarlapan O. \&Zolotov V. 2014. Effective project scheduling under workspace congestion and workflow disturbance factors. Australasian Journal of Construction Economics and Building, Conference Series, 2(1), 35-50.

33. Sijie Zhang, JochenTeizer, NipeshPradhananga\& Charles M. Eastman. 2015. Workforce location tracking to model, visualize and analyze workspace requirements in building information models for construction safety planning. Automation in Construction, 60, 74-86.

34. Spillane, J. \&Oyedele, L. 2013. Strategies for effective management of health and safety in confined site construction. Australasian Journal of Construction Economics and Building, 13(4), 50-64.

35. Spillane, P., J., Oyedele, L., O., Konanahalli, A., Mckenna, et al. 2017. Confined site construction: Issues regarding implementation of health and safety. Proceedings of 6th International Conference on Innovation in Architecture, Engineering and Construction (AEC), 1-11.

36. Spillane, J., Oyedele, L., Meding, J., Konanahalli, A., Jaiyeoba, B. \&Tijani, I. 2014. Challenges of UK/Irish contractors regarding material management and logistics in confined site construction. International Journal of Construction Supply Chain Management, 1(1), 25-42.

37. Swee Yang Low \& DKH Chua. 2017. A model for simulating and analysing workspace congestion in civil engineering job-sites. Proceedings of the International MultiConference of Engineers and Computer Scientists, 2.

38. Todd Litman. 2013. Smarter congestion relief in asian cities: win-win solutions to urban transport problems. Transport and Communications Bulletin for Asia and the Pacific, 82.

39. Vitaly Semenov, Anton Anichkin, Sergey Morozov, Oleg Tarlapan\&VladislavZolotov. 2013. Effective project scheduling under workspace congestion and workflow disturbance factors. Proceedings of the 13th International Conference on Construction Applications of Virtual Reality, 239-252 